\title{
RAÇA, RACIALIDADE E RACIALISMO: A RESSIGNIFICAÇÃO ETMOLÓGICA DE UMA PSEUDO-SOCIOLOGIA E A REVERBERAÇÃO DO ESPETÁCULO RACIAL NO CONTEXTO BRASILEIRO
}

\section{ARTIGO DE REVISÃO}

SANTOS, Yuri Tomaz dos ${ }^{1}$

SANTOS, Yuri Tomaz dos. Raça, racialidade e racialismo: A ressignificação etmológica de uma pseudo-sociologia e a reverberação do espetáculo racial no contexto brasileiro. Revista Científica Multidisciplinar Núcleo do Conhecimento. Ano 05, Ed. 10, Vol. 02, pp. 78-95. Outubro de 2020. ISSN: 2448-0959, Link de acesso: https://www.nucleodoconhecimento.com.br/comunicacao/raca-racialidade

\section{RESUMO}

Este artigo tem como objetivo discutir a semântica do termo "raça" a partir dos determinismo racialistas, bem como a proposição de ressignificação pseudosociológica da etmologia à luz da sociologia e relações sociopolíticas. Objetiva-se ainda, compreender as reverbarações dos estudos que proporiam legitimar as diferenças étnico-raciais no contexto brasileiro a partir das relações de trabalho e condicionamentos sociais. Para tanto, foram selecionadas obras que discutem as relações supracitadas, configurando e caracterizando esta pesquisa como um trabalho de revisão. Constatou-se ao final, que o termo "raça" reflete uma concepção baseada nos ideais biológicos/gênicos e que, portanto, não existe um concenso entre a semântica da etmologia. Sendo raça uma instituição latente no Brasil, o racialismo e o racismo certificam a história social do país e se manifesta como fundante de

\footnotetext{
1 Graduação em Comunicação Social/Jornalismo em andamento na Universidade Federal de Viçosa.
} 
fatores que concebem o espaço identitário homogêneo e de grandes emergências no que corresponde à racialidade e ao multiculturalismo no território.

Palavras-chaves: Raça, racialismo, ressignificação, pseudo-sociológico.

\section{INTRODUÇÃO}

O encontro com o "outro", oriundo da multinacionalização/globalização e, posteriormente, pela difusão dos ideais liberalistas, instaurou uma dicotomia racial a partir da descoberta de sujeitos e organizações socialmente "diferentes" (SCHWARCZ, 2000). Esse binarismo social concebeu estudos que proporiam explicações que legitimassem a convicção da sociedade hegemônica, ao ponto de convencionar grupos subservientes versus mando, bem como a institucionalização dos pilares sociais.

As desigudades e opressões (JAMES, 1973), se fortaleciam na medida em que os estudos, pautados na diferenciação biológica, eram realizados a partir do século XVIII, em que, a partir da fomentação do que Schwarcz (2000) classifica como sendo as ciências positivistas e deterministas, a raça era protagonizada como elemento fundante das formas de sociabilidade e estatuto de poder. Chancelados nas Ciências Biológicas, estes estudos fundamentavam a noção de raça a partir da apropriação de estudos realizados por Charles Darwin , sobretudo a partir de 1859 com a publicação da obra "A origem das espécies", e fazia surgir eugenistas a partir da explicação de diversos determinismos que configurava a "diferença” (SCHWARCZ, 2000).

No Brasil, a eugenia se torna uma discussão latente no século XIX com Raimundo Nina Rodrigues e a institucionalização das primeiras escolas de Medicina e Direito. Unido a isso, publicações realizadas por autores, como Gilberto Freyre, que não conseguiam problematizar o escravagismo, em conjunto com a banalização e o silenciamento dos país frente ao sistema anterior a 1888, ineficiência na criação de políticas e estratégias de minimar as desiguldades, oriundas do período supramencionado, fizeram com o Brasil se tornasse um território que nega a 
existência do racismo (GOMES, 2005), constituindo uma estrutura/organização resultante da história social do país.

Nesse ínterim, faz-se importante analisar como o Brasil, enquanto palco do espetáculo racial, se configura socialmente e quais percalços ou impasses foram historicamente atribuídos. Portanto, o objetivo desse trabalho é apresentar, a partir de uma revisão de pesquisas realizadas na presente pauta, quais as reverbarações de raça enquanto semântica e as colaborações provenientes das teorias eugenistas para a estrutura dos grupos étnico-raciais. Contudo, apresentar-se-á as contribuições e visões dos autores selecionados e a serem mencionados neste artigo.

Faz-se necessário elucidar que neste trabalho o termo "raça" aparecerá entre aspas quando relacionado ao âmago do léxico como uma instituição de poder e classificação dos indivíduos, baseado na cultura/etnicidade, em oposição ao uso de raça conotada como condição abstrata ou científica.

Para fins deste estudo, a priori, foi analisado um artigo da antropóloga e historiadora Lilia Moritz Schwarcz em que a "raça" é apresentada como um laboratório de estudo e dilema definidor de sujeitos a partir da perspectiva biológica. A partir das indagações e considerações da pesquisadora, buscou-se artigos que pudessem desmistificar o uso de "raça" como um léxico a ser erradicado, propondo, portanto, a ressignificação do termo a partir de uma perspectiva pseu-sociológica e com demarcações e implicações político-social dos indivíduos. Posteriomente, foi necessário a concepção de uma impressão velada de sistema de valores por parte dos europeus no Brasil. Por último, procurou por trabalhos que discorresem sobre as desiguldades no país a partir da raça/cor como elemento fundante do acondicionamento.

Sendo esta uma pesquisa de pesquisas, explanar-se-á e confrontar-se-á algumas perspectivas teóricas. Concatena-se nesse artigo as divergências e convergências entre pesquisadores com relação ao uso do termo "raça", a partir da proposição de ressignificação pseudo-sociológica, e as heranças do racialismo na sociedade brasileira a partir da apresentação dos principais pontos que concebem o Brasil como 
espaço identitário homogêneo e de grandes emergências no que corresponde à racialidade.

\section{A FUNDAMENTAÇÃO DOS DETERMINISMOS SOCIAIS A PARTIR DAS INVESTIGAÇÕES GÊNICAS}

As teses formuladas no século XIX, ensejadas no intuito de explicar e justificar a a sobreposição de raças por meio da diferenciação étnico-racial, se manifestaram como necessidades provenientes do século XVIII, que proporia uma concepção discriminada e singular entre o desenvolvimento natural dos povos oriundos das Américas pelo viés biológico (BUFFON, 1834; WEST, 1994; SCHWARCZ, 2000). Caracterizadas como teoria do "branqueamento", as teses enunciadas no século XIX se apropriariam de diversos objetos/fenômenos e teses outras para se legitimarem com relação às proposições. Tais teses fomentavam a acepção de que os sujeitos brancos teriam mais predisposição ao nascimento e à imunidade e que, por esse determinante, pautados na teoria da diferenciação oriunda de suposições genéticas, a miscigenação favoreceria o nascimento de pessoas brancas (SKIDMORE, 1989).

Ganhando cada vez mais força num contexto em que as ideologias disseminadas eram fortemente positivisitas, o racismo era mascarado, ao passo que as teses deterministas e, por conseguinte, eugenistas, eram supostamente capazes de explicar as noções de civilização. Para que essas teses pudessem ser formuladas, era preciso cindir brancos e negros, pois para o determinismo biológico os estudado precisariam se debruçar na diferença de cor. Dessa forma, a eclosão do racismo se dava de forma óbvia, bem como a fortificação da ideia de raça, fundamentada pelo estatuto de diferenciação biológica.

A partir de 1859, os "deterministas sociais" buscaram entender, a partir da obra "A Origem das Espécies" (1859), de Charles Darwin, como se dava a diferença evolutiva nos indivíduos. Assim, as teses de raça inferior e superior foram ganhando cada vez mais força, uma vez que esses cientistas analisavam o laboratório racial de duas formas: uma delas era através de fatores geográficos que acreditavam condicionar a diferenciação, e o outro, se atentava para a raça - características físicas e 
evolutivas/intelectuais como condicionante - como objeto a ser analisado. A teoria internamente incorporada, se fortificava na medida que as ideologias de que os brancos eram mais fortes e capazes em detrimento do negro se espalhavam pela Europa.

Dá-se o nome de darwinismo social ou eugenia a convicção de que as diferenças biológicas são determinantes que sobrepõe um sobre o outro trazendo a ideia de etnocentrismo, intolerância, racismo e estigmatização (SCHWARCZ, 2000). Formuladas equivocadamente pelos cientistas (COMAS, 1970), tais teses se apropriavam dos ideais darwinistas para explicar a diferença entre indivíduos brancos e negros à luz do etnocentrismo.

Para o autor,

É injusto atribuir a Darwin - como muitos o têm feito - a paternidade dessa odiosa e desumana teoria; a verdade é que as sociedades de côr se tornando competidoras potenciais no mercado do trabalho e clamando por vantagens sociais consideradas como herança exclusivas dos brancos, estes tinham, obviamente, necessidade de alguma desculpa para justificar o extremado materialismo econômico que os conduzia a negar aos povos "inferiores" qualquer participação nos privilégios que eles mesmo desfrutavam. Por esta razão, acolheram com satisfação a tese biológica de Darwin e depois, por sua simplificação, distorção e adaptação, em conformidade com seus próprios interesses, transformaram-na no chamado "Darwinismo Social", em que baseavam o seu direito de privilégios sociais e econômicos; isto é algo que não tem qualquer relação com os princípios puramente biológicos de Darwin [...] (COMAS, 1970, p. 16).

Antropólogos do período colonial, simpáticos ao determinismo ambiental e ao neodarwinismo, postulariam a concepção de raça com base nas crenças de que as diferenças poderiam ser explicadas pelas Ciência Biológicas. Em contrapartida, estudos feitos no genoma humano comprovaram que a disparidade entre as possíveis raças eram insuficientes para legitimar superioridade ou evolução para o gene oriundo de indivíduos brancos (DEL CONT, 2013; BURIAN, 2013).

Além do determinismo biológico que legitimava a supremacia branca, o determinismo climático, sugerido por Henry Thomas Buckle em 1895, auxiliou na fomentação da concepção de privilégios políticos, econômicos e intelectuais. Segundo Schwarcz, em 
sua descrição sobre o Brasil na obra "História da Civilização na Inglaterra" (1985), Buckle descreve a vegetação paisagística do Brasil como algo esplendido e desconsidera a ideia dos seres que aqui habitavam poderem usufruir ou dar algum sentido a toda essa natureza. Para ele, os "primitivos" nativos só poderiam progredir a partir do momento em que os europeus chegassem e conseguissem imprimir seus comportamentos e desenvolvimento (SCHWARCZ, 2000; BUCKLE, 1985).

De acordo com Schwarcz (2000), Gobineau (1853), acreditaria, assim como Buckle (1895), que as questões climáticas e os recursos naturais influenciavam na seleção daqueles que fossem aptos ou não, ou seja, acreditava que os nativos desapareceriam e que só poderiam sobreviver se tivesse auxílio europeu como maneira de sobrevivência. Segundo Skidmore, Gobineau diria que o determinismo social racial "fora politicamente endossado na América do Norte inglesa, onde a separação das raças "superior" e "inferior" era sistema muito bem institucionalizado" (SKIDMORE, 1989, p.45).

Por outro lado, Schwarcz diz que "quem pensa raça esquece o indivíduo, sendo esse um bom discurso no interior de um local que primou por desconhecer o Estado e anular suas instituições" (SCHWARCZ, 2000, p.32). Infere-se, portanto, que para a historiadora a antropóloga noção de raça devesse priorizar o individualismo e, grosso modo, a etmologia fosse o determinante arbitrário responsável pelo condicionamento social que fomenta o separatismo, bem como o racialismo.

No imaginário social, e também atestado por teóricos como Charles Davenport (1913), Madison Grant (1918), Lothrop Stoddard (1920; 1924), referir a indivíduos como pertencentes à determinada raça, dizer-se-á, indireta ou diretamente, sobre a existência de uma diferenciação biológica no que diz respeito às espécies humanas, o que reverberaria na acepção de classificação dos sujeitos em subespécies. Há uma convergência conceitual entre autores supracitados de que o termo deve ser utilizado para definir diferentes populações que pertencem a uma mesma espécie biológica de acordo com características fenotípicas e genotípicas. 
As teorias da diferenciação ganhavam força à medida em que os costumes e, por conseguinte, a cultura europeia era impressa no Brasil. Raimundo Nina Rodrigues, antropólogo, psiquiatra, etnólogo, professor, escritor e um dos maiores eugenistas do século XIX no país, concebeu a acepção de que a raça ariana seria responsável pela defesa dos crimes existente dentro de sua própria classe e, mais fortemente, nos atos antissociais acometidos pelas "raças inferiores". Chancelado nas teorias estrangeiras do racialismo, Rodrigues se posiciona criticamente quanto ao Código Penal Brasileiro de 1890, cuja defesa era baseada na criação de códigos penais distintos para indivíduos brancos e não-brancos publicando em 1894, seis anos após a Lei Áurea (1888), o artigo "As raças humanas e a responsabilidade penal no Brasil" (SKIDMORE, 1989; SCWARCZ, 2000).

Isso evidencia como a dimensão étnico-racial no Brasil era enunciada e como etnógrafos do período tonificariam o racialismo. Embora consideradas concepções bestiais até a segunda metade do século $X X$, faz-se necessário salientar que as escolas de medicina e de direito, no século XIX, exerceriam fortes influências nas pautas raciais, além de serem campos científicos que legitimava os fenômenos sociais.

\section{A ETMOLOGIA DE RAÇA E A CONCEPÇÃO DE SEMÂNTICA PSEUDO-SOCIOLÓGICA}

Enquanto Schwarcz (2000) apresenta a proposição dos métodos explicativos que fomentavam a segregação racial pelos darwinistas sociais, Munanga (2003), aponta alguns equívocos cometidos nos focos de estudos dos eugenistas. Para Munanga, o problema não reside nas diferenças genéticas e/ou fenotípica que os grupos étnicoraciais apresentavam e apresentam, mas na naturalização e superficialidade acerca das diferenças sociais, subordinações, complexos de inferioridade e superioridade.

Em "Uma abordagem conceitual das noções de raça, racismo, identidade e etnia" (2003), Munanga discorre como um conceito pode ser resignificado de acordo com o tempo e espaço. O antropólogo apresenta diversos usos do termo raça, bem como a etmologia da palavra que antes do século XVI era empregado para grupos que 
apresentavam características fenotípicas semelhantes, como uma descendência biológica - visto, portanto, à luz da ciência genética - e até mesmo como balizadora no tocante à classe social.

Convergindo com os estudos de Skidmore (1989), Munanga (2003) ressalta a concepção de uma "raça pura" (MUNANGA, 2003) que legitimava a ideia da supremacia branca. A partir do século XVI raça passaria ser o determinante fundante das relações sociais na França, cuja dicotomia se daria a partir dos Francos e Gauleses, sendo o primeiro se opondo à equidade e considerando ser puros racialmente $\mathrm{e}$, por conseguinte, mais habilidosos e superiores com relação ao segundo. Isso reflete "em como o conceitos de raças "puras" foi transportado da Botânica e da Zoologia para legitimar as relações de dominação e de sujeição entre classes sociais (Nobreza e Plebe), sem que houvessem diferenças morfo-biológicas notáveis entre os indivíduos pertencentes a ambas as classes" (MUNANGA, 2003, p. 1).

Nesse ínterim, o conceito de raça foi apropriado das Ciências Biológicas e incorporado no condicionamento social, passando a fomentar as divisões hierárquicas oriundas do pensamento evolutivo hegemônico. Além dessas explicações enviesadas pela ciência, a própria Teologia - que até então era o monopólio da razão - se apropriava de um discurso de evolução entre grupos, que declinaria a partir do lluminismo (MUNANGA, 2003).

Para Schwarcz (2003), raça e cor se manifestam como problemas a serem erradicados. A pesquisadora afirma,

Mal sabemos definir nossa cor e inventamos um verdadeiro carrefour de termos e nomes para dar conta da nossa indefinição nessa área. Além disso, a variedade de expressões e o caráter cotidiano de sua utilização atestam como esse é um país que ainda se apresenta e se identifica pela raça. [...] Afinal, porque é que todas as vezes que somos instados a falar de identidade voltamos à raça? Encontramos então uma série de versões que repetem e ressignificam uma certa ladainha que retorna à raça, como único porto seguro. [...] Talvez seja hora de não só deletar o racismo, mas de refletir sobre essa situação tão particular. Se, de fato, a ideia de uma democracia racial poucos adeptos tem nos dias de hoje, a constatação de que esse é um país que se define pela raça não é só importante como singular (SHWARCZ, 2000, p. 34). 
Não obstante, o âmago racial dar-se-á, no Brasil, em acordos de negação como o que foi supradito, no qual o problema estrutural se instala: no cerne do não empoderamento e autoafirmação/autodeclaração e numa possível tentativa de substituição de raça por etnia, o que, diretamente, negaria a existência de racismo. Essas duas dimensões, ainda que indissociáveis e convergentes, devem ser depreendidos como uma bipartição, uma vez que raça dentro dos Movimentos Negros conota uma orientação sociopolítica que denuncia e legitima a tênue diferenciação dos diversos dos políticos que se inserem em grupos étnico-raciais díspares ou semelhantes (GOMES, 2005; BENTES, 1993; GUIMARÃES, 1999) existente nos âmbitos econômicos, educacionais, relações sociais, no ramo trabalhista competitivo e até mesmo no sistema carcerário e taxa de mortalidade - grosso modo, podem-se comparar de jovens negros assassinados anualmente com relação à juventude branca, negligências obstétricas nos partos de mulheres negras e negação de prestação de socorro ou atendimentos médicos -, ao passo que etnia concerne ao conjunto de práticas culturais de uma organização social (língua, ritos, rituais, território etc.).

Eximindo-se da erradicação do termo, Munanga (2003), se propõe a ressignificar, etmologicamente, a convenção de raça à luz da sociologia. $O$ antropólogo é convicto da inexistência da evolução genotípica entre grupos humanos e defende que raça deve ser lido como uma diferença social entre os grupos classificados no Brasil em cinco categorias: branco, preto/negro, pardo, amarelo e indígena. Em discordância do que apresenta Schwarcz (2000), Munanga afirma que o racismo contemporâneo não está mais entrelaçado entre a acepção de raça e/ou em qualquer variante biológica e está presente também na etnia, na diferença cultural e de identidade (MUNANGA, 2003).

Em qualquer operação de classificação, é preciso primeiramente estabelecer alguns critérios objetivos com base na diferença $e$ semelhança. No século XVIII, a cor da pele foi considerada como um critério fundamental e divisor d'água entre as chamadas raças. Por sso, que a espécie humana ficou dividida em três raças estancas que resistem até hoje no imaginário coletiva e na terminologia científica: raça branca, negra e amarela. Ora, a cor da pele é definida pela concentração da melanina. É justamente o degrau dessa concentração que define a 
cor da pele, dos olhos e do cabelo. A chamada raça branca tem menos concentração de melanina, o que define a sua cor branca, cabelos e olhos mais claros que a negra que concentra mais melanina e por isso tem pele, cabelos e olhos mais escuros e a amarela numa posição intermediária que define a sua cor de pele que por aproximação é dita amarela. Ora, a cor da pele é resultante do grau de concentração da melanina, substância que possuímos todos, é um critério relativamente artificial. Apenas menos de $1 \%$ dos genes que constituem o patrimônio genético de um indivíduo são implicados na transmissão da cor da pele, dos olhos e cabelos [...] No século XIX, acrescentou-se ao critério da cor outros critérios morfológicos como a forma do nariz, dos lábios, do queixo, do formato do crânio, o angulo facial, etc. para aperfeiçoar a classificação [...] (MUNANGA, 2003, p. 3-4).

Comungando da ressigficação pseudo-sociológica de raça proposta pelo antropólogo, Nilma Lino afirma que, com relação a esta semântica,

É preciso compreender o que se quer dizer quando se fala em raça, quem fala e quando fala. Ao usarmos o termo raça para falar sobre a complexidade existente nas relações entre negros e brancos no Brasil, não estamos nos referindo, de forma alguma, ao conceito biológico de raças humanas usado em contextos de dominação, como foi o caso do nazismo de Hitler, na Alemanha. Ao ouvirmos alguém se referir ao termo raça para falar sobre a realidade dos negros, dos brancos, dos amarelos e dos indígenas no Brasil ou em outros lugares do mundo, devemos ficar atentos para perceber o sentido em que esse termo está sendo usado, qual o significado a ele atribuído e em que contexto ele surge. 0 Movimento Negro e alguns sociólogos, quando usam o termo raça, não o fazem alicerçados na idéia de raças superiores e inferiores, como originalmente era usada no século XIX. Pelo contrário, usam-no com uma nova interpretação, que se baseia na dimensão social e política do referido termo. $E$, ainda, usam-no porque a discriminação racial e o racismo existentes na sociedade brasileira se dão não apenas devido aos aspectos culturais dos representantes de diversos grupos étnicoraciais, mas também devido à relação que se faz na nossa sociedade entre esses e os aspectos físicos observáveis na estética corporal dos pertencentes às mesmas (GOMES, 2005, p. 45).

Sem problematizar os motivos pelos quais os grupos hegemônicos sempre ocuparam, histórica e estruturalmente, lugares arquitetados e dificilmente apoderados por sujeitos não-brancos, em "Raça como negociação" (2000), Lilia Schwarcz afirma que "limitar a questão racial a um problema exclusivamente econômico pouco resolve. Afirmar que a raça se esconde na classe é entender só parte da questão" 
(SCHWARCZ, 2000, p. 35). Nesse sentido, Munanga evidencia que nem todo pobre é preto, mas a maioria dos pretos são pobres.

Consciente de que a discriminação da qual negros e mestiços são vítimas apesar da "mistura do sangue" não é apenas uma questão econômica que atinge todos os pobres da sociedade, mas sim resultante de uma discriminação racial camuflada durante muitos anos, o Movimento Negro vem tentando conscientizar negros e mestiços em torno da mesma identidade através do conceito "negro" inspirado no "black" norte-americano. Trata-se, sem dúvida, de uma definição política embasada na divisão birracial ou bipolar norte-americana, e não biológica. Essa divisão é uma tentativa que já tem cerca de trinta anos e remonta à fundação do Movimento Negro Unificado, que tem uma proposta política clara de construir a solidariedade e a identidade dos excluídos pelo racismo à brasileira (MUNANGA, 2005, p.53).

Ao passo que Schwarcz (2000) indaga como falar de racismo num país em que sua população rejeita sua cor, por outro lado, Rafael Sanzio Araújo dos Anjos, no projeto Educação anti-racista: caminhos abertos pela Lei Federal n 10.639/03 (2005), propõe que haja mudança nas "práticas educacionais e a construção e divulgação de outros instrumentos de trabalho para o ensino, enfocando com seriedade a inserção do negro brasileiro na formação do Brasil" pois isso seria uma "solução para alterar esse quadro" (ANJOS, 2005, p.275).

O problema apontado por Schwarcz sobre o indivíduo abdicar seu pertencimento étnico-racial está no dado no cerne da ideologia distorcida que faz com que o negro não se sinta parte da identidade do país, problemas oriundos da inexpressividade no que diz respeito à História do Brasil e ineficacácia da adequação das escolas e discplinas aos programas e projetos federativos. De acordo com Gomes (2005), a luta contra o racismo e racialismo depende de uma reeducação individual e social e "[...] para isso, precisamos estudar, realizar pesquisas e compreender mais sobre a história da África e da cultura afro-brasileira e aprender a nos orgulhar da marcante, significante e respeitável ancestralidade africana no Brasil [...]" (GOMES, 2005, p.49) 


\section{O ESPETÁCULO RACIAL A PARTIR DA IDEOLOGIA LIBERALISTA - RELAÇÕES DE TRABALHO E DESIGULADES NO BRASIL}

Analisar o fenômeno da racialidade no Brasil, não remete, exclusivamente, em levantar debates como racismo e preconceito, mas ordena compreender "raça" como conceito e demarcador fundante da identidade de um país e, por conseguinte, sua conjuntura cultural, correspondendo às características dos grupo étnico-raciais distintos ou semelhantes entre si.

A ideia de que haveria liberdade política, econômica e das relações sociais como um todo, promoveu campos de discussão, que para os otimistas da época, aquele era o sistema que acabaria com a diferenciação e daria mais autonomia aos sujeitos. Essas ideias, no entanto, eram difundidas em conjunto com as concepções eugenistas que dominava os campos ideológicos, ou seja, o liberalismo, em consonância com o racialismo, prometeria autonomia e equidade no Brasil, que à época era o palco da espetacularização.

Em “Totalitarismo e Revolução” (1988), Ricardo Benzaquen de Araújo discute a nova face do totalitarismo que, explicada como tal, nos permite apropriar de suas teorias e aplicar em nossa discussão.

Para ele,

É preciso acentuar, contudo, que o significado da noção de totalitarismo que emprego é inteiramente diverso daquele, mais corriqueiro, que o identifica com qualquer ideologia ou regime que tenha a intenção de fazer o elogio a defesa de formas "autoritárias" de governo. Nesta concepção, totalitarismo, fascismo e autoritarismo acabam por se transformar em categorias intercambiáveis, úteis apenas para rotular e confundir, no mesmo conceito, todas as posições sociais e políticas de cunho antiliberal (ARAÚJO, 1988, p.78).

Dessa maneira, apropria-se dessa concepção neste trabalho para analisar e discutir o fenômeno da diferenciação e a crença da existência de indivíduos progressiva e biologicamente diferentes. Ao mesmo tempo, unir as ideias do liberalismo no Brasil, principalmente após a queda do Império, nos ajuda a pensar em que medida a eugenia 
era disseminada de forma coercitiva. Portanto, não pode-se considerar que os trabalhos exploratórios, a crítica aos corpos nus, as missões jesuítas com intuito de cristianizar os "pagãos", o escândalo que a poligamia causava, a necessidade de tornar estrangeiro o que era nacional, a indicação das novas formas de vivências, a escravização fundamentada na inferioridade da raça e a tentativa de "domesticar" seriam atitudes de civilizações que estavam simplesmente bestializadas como uma forma diferente de viver e ser. Isso são atitudes autoritárias que, como salienta Araújo (1988), não são simplesmente atitudes que dizem respeito às formas autoritárias de governo.

A releitura desse processo é perceptível quando afirma que "a proposta totalitária vai implicar sempre na defesa de uma totalização absoluta, homogeneizante, disposta a eliminar todas as particularidades e diferenças, contidas no interior do corpo social, pela ação de uma ideologia unificadora [...]" (ARAÚJO, 1988, p. 80).

A proposta de homogeneização era dada na medida em que os europeus imprimiam constumes e cultura aos povos originários e sujeitos não-brancos, isto é, uma homogeneidade pautada na perspectiva de branqueamento e na estrangeirização dos nativos (SCHWARCZ, 2000), ou seja, havia um paradoxo entre o fenômeno da diferenciação, estimulada pela globalização a partir do encontro com o "outro", e a necessidade de unificar as Américas segundo costumes europeus.

Nessa ínterim, percebe-se como o totalitarismo se apresentava disfarçado e camuflado em uma nova faceta para o racialismo, uma vez que a ideia não era apresentar práticas culturais outras aos índios e negros, mas mostrar a supremacia racial - de modo furtivo e acautelado - que os brancos acreditavam pertencer, impor práticas balizadas no eurocentrismo - fala-se de crenças, heranças, costumes, práticas, vivências, processos históricos e sociais - e conceber indigenas e negros como sujeitos designados à objetificação/instrumentalização para o desempenho e desenvolvimento laborativo, ou seja, dedicados exclusivamente à subserviência trabalhista. 
Sob a análise das teorias de Plínio Salgado, Araújo (1988), se posiciona com relação à incapacidade de visualizar o período da colonização brasileira como um sistema sagazmente totalitário que impossibilita vislumbrar as condições supramencionadas de forma subjetiva e passiva, sem considerar o ethos identitário europeu. Afirma,

Identificado o nacional com o popular, e dando a este o sentido de uma totalidade homogênea, sem divisões, Plínio vai atribuir grande valor às sociedades organizadas sob a forma de nação, ponto de partida da "síntese superior" que deverá caracterizar a civilização integralista. Acontece que, ao contrário da Itália e da Alemanha, onde "existia anteriormente um "espírito nacional consciente", existia uma nação, no Brasil nada disso existia. Cumpria criar a Nação" (cf. Salgado, 1937b, p.182). Ora se nos lembramos do que Plínio havia indicado a colônia como a única época em que o "Brasil fora realmente brasileiro", não haverá, então, causar-nos surpresa que ele recorra exatamente a esse período em busca de um primeiro modelo para a nacionalidade brasileira (ARAÚJO, 1988, p. 65).

Enquanto Schwarcz vê o liberalismo como fomentador das teorias e teses eugenistas a partir da ascensão da República após a queda do Império no fim do século XIX, Araújo, sob análise do já século XX, em contrapartida afirmar que,

Deve-se observar, entretanto, que esta aliança, esta similaridade entre o totalitarismo e o conservadorismo, termina exatamente aqui, nesta mútua negação da doutrina liberal. $\mathrm{Na}$ verdade, aquele espaço de concordância de que fala acima possui limites bastante estreitos, pois compreende somente o diagnóstico da crise que assola a modernidade, crise que teria no liberalismo, no relativismo e na desagregação por ele estimuladas, o seu grande e exclusivo culpado (ARAÚJO, 1988, p. 79).

Com relação ao colonialismo, sem dúvidas um dos maiores legados do período escravagista está dados nas formas de concepção e divisão do trabalho. Depois de difundirem a ideia do "mito das três raças" (CASTRO, 1998), bem como afirmaria também Schwarcz em Raça como negociação (2000), houve uma maior aceitação de que o negro, o branco e o miscigenado faziam parte da construção identitária do Brasil. No entanto,

[...] A recusa de integridade étnica dos grupos sociais conviveu com a forte diferenciação social fundada em características de tipo de racial, fenotípicas, que existiam em elementos como a cor da pele, a conformação do nariz, a finura do cabelo. Os sinais físicos tornaram-se 
importantes elementos no sistema de classificação social subjacente à lógica de estruturação dos lugares sociais (CASTRO, 1998, p. 23).

Isto é, mesmo que houvesse uma maior "aceitação" de que a construção da identidade do país pudesse estar inserida no que tange as "três raças", a eficácia dessa anuência reverberam em condicionamentos que ainda perduram, haja vista a hierarquização de grupos que hoje ocupam o mercado de trabalho no Brasil.

As desigualdades sociais podem - e devem - serem vistas como oriundas da fenomenologia de cor. Não obstante, é preciso perceber, como propõe Castro (1998), que por muito tempo os meios acadêmicos, bem como estudos difundidos por teóricos desvanecidos a partir dos anos 30, como Gilberto Freyre, acreditavam que as diferenças de classe é anterior à diferença de raça e preconceito, como salienta a autora, isto é, houve um acordo de que a escravidão como sistema de exploração se explicava pela busca incessante por lucros e acúmulo de riqueza, o que faz com que o racialismo e o racismo, dado a partir da subordinação dos não-brancos e a supremacia hegemônica, pudessem ser explicados como um fenômeno exploratório contingente e imprevisível.

De forma crítica, Castro discorre em Trabalho e desigualdades raciais: hipóteses desafiantes e realidades por interpretar (1998), sobre a contemplação de Gilberto Freyre que analisa o fenômeno da eugenia e diferenciação como "democracia racial".

Na tentativa de recusar as ideias de conteúdo racista então fortemente correntes - como as de Vianna (1952) -, essa linha de interpretação sustentava a argumentação da contribuição positiva que africanos e indigentes teriam aportado à cultura brasileira. Tais contribuições eram concebidas como o resultado de dois fatores principais: a plasticidade da estratégia colonial portuguesa, de tipo inclusivista, e a ampla miscigenação racial. Essa concepção sustentou o ponto de vista de que - Brasil seria um exemplo de "democracia racial", juízo amplamente difundido sobretudo nos escritos de Gilberto Freyre (1933). Como um corolário implícito, assumia-se que o preconceito racial e a discriminação nunca teriam existido no Brasil, ao menos como formas ativas de configurar as oportunidades econômicas e sociais para negros e brancos (CASTRO, 1998, p. 24). 
Contudo, enfatiza-se que as características econômicas seriam determinantes importantes a serem estudados para compreender a história social do trabalho brasileiro juntamente com as disparidades sociais legadas. Para explicar essa desigualdade, Castro, chancelada nas linhas de interpretação de teóricos como Carlos Hasenbalg, Nelson do Valle Silva, Florestan Fernandes, discorre sobre o contraste social brasileiro a partir da raça como determinante categórico e condicionante das relações sociais.

De acordo com Castro (1998), as desigualdades para Fernandes se justificavam pela produção industrial em união à política de importação. Com a defasagem da sociedade agrária escravocrata e a ascensão do capitalismo industrial, principalmente em São Paulo, é concebida como uma herança implantada nesse novo sistema, a partir do "abandono" das práticas agrárias, herdadas a partir das relações escravagistas (CASTRO, 1998).

Ao fazer menção à Hasenbalg e Valle Silva, Castro (1998) discorre que ambos os autores justificariam as "diferenças" com as mesmas explicações fomentadas durante os anos 70 e 80 . Os autores supracitados, além de dialogarem sobre o etnocídio e a segregação social imposta aos negros, têm como objeto de estudo a indústria capitalista, sobretudo no pós-abolição. Além disso, trabalhariam ainda com a ideia da segregação geográfica que alocou grande parte de negros na região nordeste do Brasil, tornando aquele um dos maiores pontos de trabalho negro do país (CASTRO, 1998).

Outrossim, é o não ingresso em escolas motivada pelo entrada repentina no mercado de trabalho. Isso, implica na alimentação da desigualdade pois, enquanto negros ocupam as pirâmide do trabalho em maior grau, os não-negros que tem acesso à educação, consequentemente e obrigatoriamente ocuparão os melhores cargos, ganharão os melhores salários e, logicamente, explorarão os que não tiveram acesso em função da luta pela sobrevivência - nada mais, nada menos que os negros. Dessa forma, a desigualdade é maximizada em função do não acesso ou da união simultânea de trabalho e estudo - aqui estamos tratando de trabalhos pesados e marginalizados em função da luta pela sobrevivência e a competição que há no mercado de trabalho. 
Os dados do Instituto de Pesquisa Econômica Aplicada (Ipea), com última versão atualizada em 2009, considerando a população com 16 anos de idade ou mais, apontam o número de 5,94\% para brancos e $13,42 \%$ para negros com relação à taxa de analfabetismo. Para a taxa de desemprego o Ipea apresenta 6,6\% para homens negros, 5,3\% para homens brancos, 12,5\% para mulheres negras e 9,2\% para mulheres brancas. Já a média de anos de estudo varia em 6,8\% para homens negros, $8,8 \%$ para homens brancos, $7,8 \%$ para mulheres negras e $9,7 \%$ para mulheres brancas. Esses dados são evidências da evasão escolar ou da inacessibilidade da população negra à educação, sobretudo das mulheres, o que incide, hipoteticamente, no aumento do acesso ao trabalho de modo informal, ou seja, sem carteira assinada.

Gomes (2005), num olhar acurado sobre a fomentação da desigualdade racial no Brasil, apresenta esse problema como sendo oriundo da ideia de democracia racial lançada a partir de 1888 em que a abolição da escravidão legalmente compreendida apresentava um tônus idealista de equidade, haja vista o menosprezo quanto a criação de formas eficazes ao combate do racismo e políticas de sancionamento após a abolição.

Gomes afirma que,

A sociedade brasileira, ao longo do seu processo histórico, político, social e cultural, apesar de toda a violência do racismo e da desigualdade racial, construiu ideologicamente um discurso que narra a existência de uma harmonia racial entre negros e brancos. Tal discurso consegue desviar o olhar da população e do próprio Estado brasileiro das atrocidades cometidas contra os africanos escravizados no Brasil e seus descendentes, impedindo-os de agirem de maneira contundente e eficaz na superação do racismo (GOMES, 2005, p.56).

Destarte, é preciso escurecer que, no Brasil, esses problemas são provenientes da negação da existência do racismo e das narrativas de vivências harmônicas entre brancos e pretos/negros, bem como das incoformidades ideológicas e comunitárias causadas à população que, embraquecida racionalmente no corresponde às relações étnico-raciais no Brasil, tendem à suscitar e conformar as inconsistências raciais fundamentadas pela história social. 


\section{CONSIDERAÇÕES FINAIS}

Entender a construção da identidade e os fenômenos raciais do Brasil, só é possível na medida em que faz-se um recuo temporal, analisando objetos, fatores e o ethos social, sendo estes extremamente coercitivos na formação cultural do país, configuram uma espetacularização das relações e acordos étnico-raciais.

Procurou estabelecer neste artigo uma coerência entre os determinismos racialistas em consonância com as relações étnico-raciais latentes e presentes no Brasil. Conclui-se que as desigualdades e a necessidade de uma higienização social e a ideia de uma equidade entre grupos racialmente diferentes prevalecem institucionalizados e introjetados na subjetividade dos sujeitos.

Ao mesmo tempo, percebeu-se como não há um consenso entre os pesquisadores com relação ao uso do termo "raça" para classificar uma condição política e pseudosociológica de grupos racialmente e etnicamente diferentes no que corresponde as formas de opressão, determinantes econômicos/educacionais/institucionais/relações de trabalho e a distinção de quais corpos políticos são suscetíveis à homicídios.

Refletindo os problemas de um país que se funda a partir de relações racistas e invasivas, a educação antirracista, como discorrido no decorrer deste trabalho, teria responsabilidades singulares na capacitação e formação cidadã. A partir disso, é possível propor que os meios de comunicação, pouco expressivos em conteúdos que reverberam uma pedagogia politicamente educativa, veiculem anúncios, propagandas, documentários e mini palestras seriadas/continuadas de forma crítica, multicultural e de valor informativo. Ao mesmo tempo que essa alternativa possa parecer incerta, haja vista a possibilidade de haver propagação de discursos ideológicos tendenciosos e intolerantes, o respaldo constitucional com monitoramento de tais produções configuraria enunciações midiáticas certificadas e autênticas. 


\section{REFERÊNCIAS}

ANJOS, Rafael Sanzio Araújo dos. A África, a educação brasileira e a geografia. In: In: BRASIL. Educação Anti-racista: caminhos abertos pela Lei federal oㅜ 10.639/03. Brasília, MEC, Secretaria de educação continuada e alfabetização e diversidade, pp.167-184, $2005 . \quad$ Disponível em: http://www.dominiopublico.gov.br/pesquisa/DetalheObraForm.do?select_action=\&co _obra=16224. Acesso em: 23 de outubro de 2019.

ARAÚJO, Ricardo Benzaquen de. Totalitarismo e revolução - O Integralismo de Plínio Salgado. Rio de Janeiro: ATP, 1988.

BENTES, Raimunda Nilma de Melo. Negritando. Belém: Graphitte, 1993.

BURIAN, Richard. On Gene Concepts and Teaching Genetics: Episodes from Classical Genetics, Science \& Education, vol. 22, no 2, pp.324-344, 2013. Disponível em: https://link.springer.com/article/10.1007/s11191-011-9367-y. Acesso em: 26 de setembro de 2017.

BUCKLE, Henry Thomas. History of the English civilization. London, s.e., 1845.

BUFFON, Georges-Louis Leclerc. Oeuvrers complètes. Paris: Pouvrat Frères, 1834.

CASTRO, Nadya Araujo. Trabalho e desigualdades raciais. Negros e brancos no mercado de trabalho em Salvador. Org. CASTRO. Nadya Araujo, BARRETO, Vanda Sá. São Paulo: Annablume, 1998.

CHARLES, Darwin. A Origem das Espécies. São Paulo: Hemus, 1 ed. 1859.

COMAS, Juan. Os mitos raciais. In: Raça e Ciências. São Paulo: Perspectiva S.A, 1970.

DEL CONT, Valdeir. O controle de características genéticas humanas através da institucionalização de práticas socioculturais eugênicas, Scientiae Studia, vol. 11, no 3, pp.511-530, 2013. 
DAVENPORT, Charles Benedict. Heredity of Skin-Color in Negro-White Crosses. Washington, D. C., Carnegie institution of Washington, 1913.

DUARTE, A. C. A Constitucionalidade das Políticas de Ações Afirmativas. Brasília: Núcleo de Estudos e Pesquisas/CONLEG/Senado, abril/2014 (Texto para Discussão no 147). Disponível em: https://www12.senado.leg.br/publicacoes/estudoslegislativos/tipos-de- estudos/textos-para-discussao/td-147-a-constitucionalidadedas-politicas-de-acoes-afirmativas. Acesso em 8 de novembro de 2017.

FIGUEIREDO, Ariosvaldo. O negro e a violência do branco: o negro em Sergipe. Rio de Janeiro: J. Álvaro, 1977.

GOBINEAU, Arthur de. Essai sur l'inégalité des races humaines. Paris: GallimardPleiade, 1 ed. 1853.

GOMES, Nilma Lino. Alguns termos e conceitos presentes no debate sobre relações raciais no Brasil: uma breve discussão. In: BRASIL. Educação Anti-racista: caminhos abertos pela Lei federal $n^{0}$ 10.639/03. Brasília, MEC, Secretaria de educação continuada e alfabetização e diversidade, pp.39-62, 2005. Disponível em: http://www.dominiopublico.gov.br/pesquisa/DetalheObraForm.do?select_action $=\&$ co_obra=16224. Acesso em: 23 de outubro de 2019.

GRANT, Madison. The passing of the great race, or, The racial basis of European history. Nova ed., rev. e ampliada, com prefácio de Henry Fairfield Osborn. Nova York, Charles Scribner's Sons, 1918.

GUIMARÃES, Antônio Sérgio Alfredo. Racismo e Anti-Racismo no Brasil. São Paulo: Editora 34, 1999.

IPEA - INSTITUTO DE PESQUISA ECONÔMICA APLICADA; IBGE - INSTITUTO BRASILEIRO DE GEOGRAFIA E ESTATÍSTICA. Relatório econômico. Brasília: Ipea; IBGE, 2009. Relatório estatístico. Brasília: Ipea; IBGE, 2009. Disponível em: 
https://www.ipea.gov.br/portal/index.php?option=com_content\&view=article\&id=6183 \&catid=10\&ltemid=9. Acesso em: 12 de abril de 2020.

JONES, James McCoy. Racismo e Preconceito. São Paulo: Edgard Blücher Ltda, 1973.

LÉVI-STRAUSS, Claude. Raça e História. In: COMAS, Juan (org.). Raça e Ciência. São Paulo: Perspectiva S.A, 1970.

MUNANGA, Kabengele. GOMES, Nilma Lino. Para entender o negro no Brasil de hoje: história, realidades, problemas e caminhos. São Paulo: Global; Ação Educativa, 2004.

Algumas considerações sobre "raça", ação afirmativa e identidade negra no Brasil: fundamentos antropológicos. REVISTA USP, n. 68, pp.46-57, 2006, .

SCHWARCZ, Lilia Katri Moritz. Raça como negociação: Sobre teorias raciais em finais do século XIX no Brasil. In: FONSECA, Maria de Narareth Soares (org.). Brasil AfroBrasileiro. Belo Horizonte: Autêntica, p.13-40, 2000.

Retrato em branco e negro: Jornais, escravos e cidadãos em São Paulo no final do século XIX. São Paulo: Companhia das Letras, 1987.

SEVCENKO, Nicolau. A revolta da vacina: mente insanas em corpos rebeldes. São Paulo: Brasiliense, 1984.

SKIDMORE, Thomas Elliot. Preto no Branco: Raça e Nacionalidade no Pensamento Brasileiro. Rio de Janeiro: Paz e Terra, 2 ed. 1976.

STODDARD, Lothrop. The Rising Tide of Color Against White World-Supremacy. Nova York: Charles Scribner's Sons, 1920.

Racial Realities in Europe. Nova York: Charles Scribner's Sons, 1924. 
TODOROV, Tzvetan. Nós e os outros: a reflexão francesa sobre a diversidade humana. Rio de Janeiro: Jorge Zahar, 1993.

VAINFAS, Ronaldo. Dicionário do Brasil Colonial - 1500-1808. Rio de Janeiro: Objetiva, 2000.

VENTURINI, Anna Carolina. Ações Afirmativas na Pós-Graduação e a Diversidade. $18^{\circ}$ Congresso Brasileiro de Sociologia. Brasília, 2017, 20 p.

WEST, Cornel. Questão de raça. São Paulo: Companhia das Letras, 1994.

Enviado: Julho, 2020.

Aprovado: Outubro, 2020. 